\title{
Effect of Increasing Yolk Testosterone Levels on Early Behaviour in Japanese Quail Hatchlings
}

\author{
M. OKULIAROVÁ ${ }^{1}$, P. ŠKROBÁNEK ${ }^{2}$, M. ZEMAN ${ }^{1,2}$ \\ ${ }^{1}$ Department of Animal Physiology and Ethology, Faculty of Natural Sciences, Comenius University, \\ Bratislava, Slovakia \\ ${ }^{2}$ Institute of Animal Biochemistry and Genetics, Slovak Academy of Sciences, Ivanka pri Dunaji, \\ Slovakia \\ Received January 12, 2007 \\ Accepted August 27, 2007
}

\begin{abstract}
Okuliarová M., P. Škrobánek, M. Zeman: Effect of Increasing Yolk Testosterone Levels on Early Behaviour in Japanese Quail Hatchlings. Acta Vet. Brno 2007, 76: 325-331.

The aim of our study was to investigate effects of increased testosterone content in egg yolk on early behaviour of 1- and 2-day-old Japanese quail. Three different doses of testosterone $(0.25 ; 2.5$ and $25 \mathrm{ng})$, not exceeding a physiological range, were examined in three separate experiments. Testosterone propionate dissolved in $20 \mu \mathrm{l}$ olive oil was injected into the yolk before the onset of incubation.

Behaviour of newly hatched chicks was recorded in response to both a novel environment in the open-field test and manual restraining in the test of tonic immobility (TI). Behavioural consequences of embryonic exposure to elevated testosterone were observed in the open-field test in all three experiments which indicated inhibition of behavioural responses in hatchlings. Birds treated with testosterone in ovo displayed longer latency to leave the start square, decreased locomotor activity, enhanced defecation and lower number of distress calls as compared to control birds. In TI test, the influence of treatment was manifested at the highest concentration only. Hatchlings from testosterone treated eggs expressed longer duration of TI and required less attempts to induce TI in comparison with the control group.

Our results demonstrated increased fearfulness of Japanese quail chicks hatched from eggs with experimentally elevated testosterone content. The effect is specific for a short period after hatching since previous studies reported stimulatory effect of yolk testosterone on behaviour of Japanese quail later in ontogeny.
\end{abstract}

Maternal hormones, testosterone, quail, behaviour, ontogeny

Early postembryonic period is a critical stage in development of avian species mainly because it is carrying much more risk than protected conditions in the egg and newly hatched chicks must cope with unfamiliar challenges from the external environment. Appropriate behavioural responses of individuals may reflect epigenetic adaptations that are formed as a result of conditions to which they are exposed in embryonic milieu (Horton 2005). Therefore laying hens may influence phenotypic development of their progeny not only by providing basic genetic information but also by depositing nutrients and biologically active substances into their eggs. It is well known that lipid soluble vitamins and antioxidants are necessary for successful embryonic development, including posthatching growth, health status and future performance of hatchlings (Surai et al. 1998; Karadas et al. 2005). Current research is focused on maternal hormones as other significant components of egg yolk that may substantially affect an ability of offspring to cope with their environment (Groothuis et al. 2005). Steroid and thyroid hormones are predominantly important in this consideration since their mechanism of action involves a control of gene expression. Moreover, early exposure to these hormones usually produces longlasting consequences later in ontogeny (Schlinger 1998). Experimentally enhanced androgen concentrations in eggs have been shown to stimulate postincubation growth and begging

Address for correspondence:

Prof. RNDr. Michal Zeman, DrSc.

Department of Animal Physiology and Ethology

Comenius University, Mlynská dolina B - 2

84215 Bratislava, Slovakia
Phone: + 421260296424

Fax: + 421265429064

E-mail: mzeman@fns.unib.sk

http://www.vfu.cz/acta-vet/actavet.htm 
behaviour in hatchlings of altricial and semiprecocial wild-living birds (Schwabl 1996; Eising and Groothuis 2003).

Behavioural data from precocial species indicate that young quail chicks hatched from testosterone treated eggs exhibit less fearfulness in both a novel object test and tonic immobility test. In other words, they adopt "proactive" behavioural strategy (Daisley et al. 2005). The conclusion is supported also by our previous study in male Japanese quail. Nine-day-old birds hatched from eggs treated with testosterone showed increased activity in response to a novel environment (Okuliarová et al. 2006). Thus, maternal hormones may participate in forming individual responses to the same stimulus that means they may increase variability in phenotypic traits, which in turn increase survival and reproductive success (Groothuis and Carere 2005).

Most studies in this field usually include treatment of eggs with only androgen concentration nearing the upper physiological limit. In the present study, we examined three different doses of testosterone, with one hundred-fold difference between the lowest and the highest concentration, that still were in a physiological range. The specific effects of increasing hormone content in eggs were assessed using this experimental approach. Based on the results of previous research, it was hypothesized that experimentally enhanced yolk testosterone content will have a stimulatory effect on early behaviour in 1- and 2-day-old quail hatchlings.

\section{Materials and Methods}

Our study consisted of three separate experiments (E1, E2 and E3) using Japanese quail (Coturnix japonica) as a model of poultry species. Identical experimental protocols were utilized for all three experiments, differing only in the dose of testosterone administered into the egg yolk.

Quail eggs were obtained from a breeding colony housed at the Institute of Animal Biochemistry and Genetics, SASci, Slovakia. Per each experiment, quail were randomly assigned into one of two groups, a testosteronetreated $(\mathrm{T})$ and a control $(\mathrm{C})$, respectively. Just prior to incubation, all eggs of the testosterone-treated group were injected with the required concentration of testosterone propionate (Agovirin, Léčiva, Czech Republic) dissolved in $20 \mu \mathrm{l}$ olive oil. In E1, eggs of the T-group $(n=107)$ received $0.25 \mathrm{ng}$ testosterone and eggs of C-group $(n=72)$ were left intact. In E2, the dose of $2.5 \mathrm{ng}$ testosterone was administered into each egg of T-group $(n=35)$ and eggs of C-group $(n=40)$ were injected with $20 \mu$ olive oil. In E3, eggs of T-group $(n=93)$ were treated with $25 \mathrm{ng}$ testosterone and eggs of C-group $(\mathrm{n}=90)$ received $20 \mu \mathrm{l}$ olive oil.

At first, the eggshell was disinfected with $70 \%$ ethanol and injections were made through the blunt pole of the egg into the yolk. After injection, the hole was sealed with paraffin. Eggs were placed into a forced draught incubator (Bios Midi, Czech Republic) with automatic turning and incubated in constant darkness at $37.0 \pm 0.2$ ${ }^{\circ} \mathrm{C}$ and relative humidity of 50-60\%. After hatch, quail chicks were leg-banded with colour rings and placed in separate cages according to their treatment group. Birds were housed under continuous light and temperature maintained at $35-37^{\circ} \mathrm{C}$. Quail were fed young turkey mash and water was provided ad libitum. Chick body weights were recorded before starting the behavioural tests on day of hatch.

Open-field test

The open-field test was performed among a sampling of 1-day-old hatchlings outside the breeding room. Quail (62) were placed in a wooden box measuring $25 \times 25 \times 25 \mathrm{~cm}(\mathrm{w} \times 1 \times \mathrm{h})$ with white painted walls and floor divided into 25 equal squares. The box was situated in an area with temperature corresponding to the temperature in the breeding room. Each bird was individually placed into the central square of the box and after 10 seconds its behaviour was recorded by video camera for 15 minutes. The following behavioural categories were analysed from the videotapes: locomotor activity (number of lines crossed), vocalization (number of distress calls emitted), pecking (number of both wall- and floor-pecks), attempts to escape (number of jumps), defecation (number of defecations) and latency to explore (leave the start square), latency to vocalize (first call) and latency to defecation.

\section{Tonic immobility test}

Quail hatchlings (168) were tested for their tonic immobility (TI) responses between 1 and 2 days of age. Each bird was removed from its cage mates and carried individually into a separate testing room. The state of TI was induced by placing the bird on its back in a cardboard V-shaped model with one hand over its body and another one slightly over its head (Jones et al. 1994). The hand pressure was released after $10 \mathrm{~s}$ and the duration of TI was measured when chick stayed immobile longer than $5 \mathrm{~s}$. Maximum score for TI duration was $300 \mathrm{~s}$. If TI could not be induced by three repeated attempts, the bird was returned back into the home cage and its TI duration was given $0 \mathrm{~s}$. The number of attempts required to induce TI as well as duration of TI was recorded.

Statistical analysis

All data were examined for normality and homogeneity of variance and analysed using either Student's $t$-test or non-parametric Mann-Whitney test. 


\section{Results}

Experimental injections had no impact on hatch success of chicks between controls $(40.3 \%, 57.5 \%$ and $50.0 \%)$ and testosterone-treated $(32.7 \%, 54.3 \%$ and $39.8 \%)$ groups, respectively.

Testosterone treatment did not affect hatching body weight of chicks in both E1 and E2 ( 0.25 and $2.5 \mathrm{ng}$ testosterone). However, hatchlings from eggs treated with the highest dose $(25 \mathrm{ng})$ of testosterone had significantly reduced body weight as compared to control chicks $(\mathrm{t}=2.554 ; p<0.05$; mean \pm SEM for C-group $6.82 \pm 0.08 \mathrm{~g}$ and $6.54 \pm 0.08 \mathrm{~g}$ for T-group).

Responses measured in the tonic immobility test differed between the control and testosterone-treated group after administration of the highest concentration of testosterone (Experiment 3). Quail hatched from testosterone-treated eggs showed longer duration of TI $(\mathrm{T}=1706 ; p<0.05 ;$ Fig. $1 \mathrm{~A})$ and required fewer attempts to induce $\mathrm{TI}(\mathrm{T}=1216 ; p<0.05$; Fig. 1B) as compared to control birds. Treatments with both lower doses of testosterone $(0.25$ and $2.5 \mathrm{ng})$ did not influence TI reactions in hatchlings. However, chicks exposed to $2.5 \mathrm{ng}$ of testosterone exhibited a trend to longer duration of TI $(\mathrm{T}=452 ; p=0.093)$ than control birds.
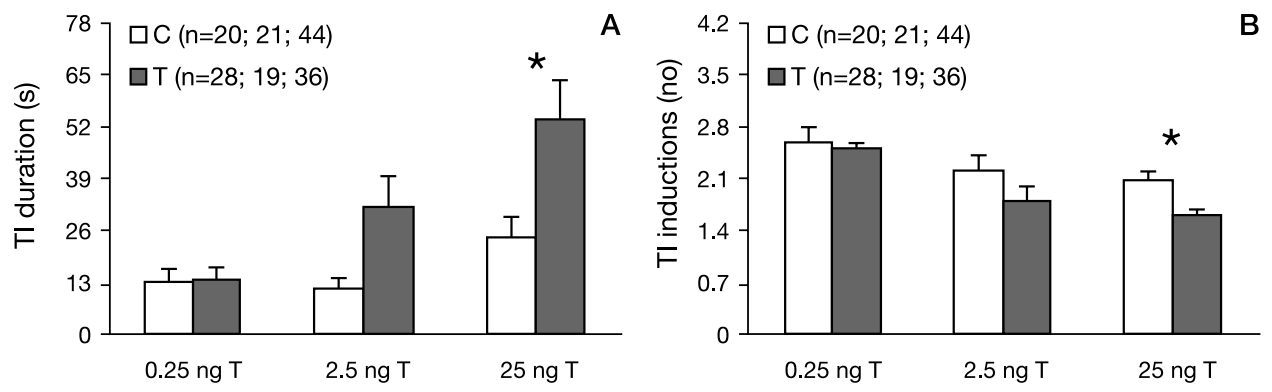

Fig. 1. Tonic immobility duration (A) and number of TI inductions (B) in 2-day-old Japanese quail hatched from control (C) and testosterone-treated $(\mathrm{T})$ eggs with three different doses of testosterone. Values represent means \pm S.E.M., ${ }^{*} p<0.05$.

Behavioural observations in the open-field test revealed a significant effect for quail treated with experimentally increased testosterone content in eggs (Table 1). Hatchlings exposed to $2.5 \mathrm{ng}$ of testosterone emitted a lower number of distress calls as compared to the control group $(\mathrm{t}=2.285 ; p<0.05)$. The main treatment effect on decreased vocalization was observed during the first 5 minutes of the open-field test (Fig. 2). Significant differences between chicks hatched from control and testosterone-treated eggs were found after the administration of both $2.5 \mathrm{ng}(\mathrm{t}=2.492 ; p<0.05)$ and $25 \mathrm{ng}$ $(\mathrm{t}=2.896 ; p<0.01)$.

Quail hatched from eggs treated with the lowest dose of testosterone $(0.25 \mathrm{ng})$ displayed both longer latency to explore $(\mathrm{T}=77.5 ; p<0.05)$ and higher defecation rates $(\mathrm{T}=67$; $p<0.01)$ as compared to the control group. Similarly, increased number of defecations $(\mathrm{T}=67 ; p<0.01)$ together with shorter latency to defecation $(\mathrm{T}=145.5 ; p<0.05)$ were found in hatchlings exposed to testosterone at the dose of $2.5 \mathrm{ng}$ as compared to control birds. In Experiment 2, quail hatched from testosterone-treated eggs showed a trend to decreased locomotor activity $(\mathrm{t}=1.925 ; p=0.069)$ and exhibited a significantly higher number of jumps $(\mathrm{T}=79 ; p<0.05)$ than controls. Differences in behaviour in $\mathrm{E} 3$ were observed in a trend toward a longer latency to explore which was demonstrated among chicks hatched from testosteronetreated eggs $(\mathrm{T}=84.5 ; p=0.078)$ as compared to the control. 
Table 1. Open-field behaviours in 1-day-old quail chicks hatched from control (C) and testosterone-treated (T) eggs with three different concentrations of testosterone $(0.25 ; 2.5$ and $25 \mathrm{ng})$.

\begin{tabular}{|l|c|c|c|c|c|c|}
\hline \multirow{2}{*}{} & \multicolumn{2}{|c|}{ E1 $(0.25 \mathrm{ng})$} & \multicolumn{2}{c|}{ E2 $(2.5 \mathrm{ng} \mathrm{T})$} & \multicolumn{2}{c|}{ E3 (25 $\mathrm{ng} \mathrm{T})$} \\
\cline { 2 - 7 } & $\mathrm{C}, \mathrm{n}=10$ & $\mathrm{~T}, \mathrm{n}=10$ & $\mathrm{C}, \mathrm{n}=10$ & $\mathrm{~T}, \mathrm{n}=11$ & $\mathrm{C}, \mathrm{n}=10$ & $\mathrm{~T}, \mathrm{n}=11$ \\
\hline Number of lines crossed & $569.1 \pm 73.6$ & $640.3 \pm 91.5$ & $751.3 \pm 71.6$ & $570.4 \pm 61.6$ & $611.4 \pm 50.2$ & $533.3 \pm 92.3$ \\
\hline Number of calls & $609.3 \pm 59.4$ & $569.7 \pm 48.2$ & $817.4 \pm 54.0$ & $651.9 \pm 48.6^{*}$ & $640.1 \pm 78.7$ & $470.6 \pm 48.3$ \\
\hline Number of jumps & $72.5 \pm 18.5$ & $52.2 \pm 19.7$ & $29.1 \pm 12.2$ & $56.1 \pm 11.0 *$ & $33.5 \pm 12.8$ & $35.2 \pm 13.2$ \\
\hline Number of pecks & - & - & $291.2 \pm 44.0$ & $313.1 \pm 37.7$ & $247.7 \pm 44.0$ & $259.1 \pm 48.2$ \\
\hline Number of defecations & $0.3 \pm 0.2$ & $1.2 \pm 0.1 * *$ & $0.4 \pm 0.2$ & $1.0 \pm 0.1 *$ & $0.9 \pm 0.2$ & $0.9 \pm 0.2$ \\
\hline Latency to vocalize (s) & $2.1 \pm 1.2$ & $20.2 \pm 11.8$ & $6.6 \pm 6.6$ & $8.4 \pm 5.1$ & $0.0 \pm 0.0$ & $10.8 \pm 9.5$ \\
\hline Latency to explore (s) & $13.9 \pm 7.9$ & $50.7 \pm 19.2 *$ & $14.0 \pm 9.4$ & $22.8 \pm 8.8$ & $4.3 \pm 1.9$ & $23.3 \pm 13.4$ \\
\hline Latency to defecation(s) & - & - & $721.7 \pm 109.3$ & $273.4 \pm 97.3 *$ & $391.5 \pm 134.9$ & $246.4 \pm 99.6$ \\
\hline
\end{tabular}

Data are presented as means $\pm \mathrm{SEM}, * p<0.05, * * p<0.01$.

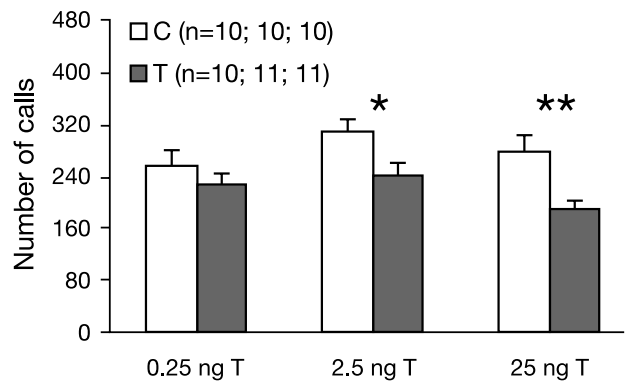

Fig. 2. Vocalization of 1-day-old Japanese quail in the first 5 minutes of the open-field test. C-control groups, $\mathrm{T}$ - testosterone-treated groups. Values are presented as means \pm S.E.M., ${ }^{*} p<0.05,{ }^{* *} p<0.01$.

\section{Discussion}

Administration of testosterone into the egg yolk modified behavioural responses of Japanese quail hatchlings measured in two separate behavioural tests. Endogenous androgen concentrations in avian eggs are strongly species-specific and can differ both between eggs of individual females and within the order of laying sequence (Reed and Vleck 2001; Pilz et al. 2003; Groothuis et al. 2005). Recent studies in Japanese quail have determined endogenous levels of yolk testosterone in the range from $4 \mathrm{ng}$ (Hayward et al. 2005) to 30 $\mathrm{ng} / \mathrm{g}$ yolk (Hackl et al. 2003). Since our unpublished egg yolk testosterone determination is in agreement with these amounts, it was expected that the three tested testosterone doses $(0.25 \mathrm{ng}, 2.5 \mathrm{ng}$, and $25 \mathrm{ng})$ increased content of yolk androgens within the range of naturally occurring levels.

Results of the present study show that open-field behaviours of quail hatchlings were affected by elevated yolk testosterone content at all three concentrations. Social isolation and an unfamiliar environment are two types of stressful events which can elicit fearful behaviour among the quail that underwent open-field testing (Marin et al. 1997). In poultry species, fear can be associated with longer immobility period and inhibition of exploratory behaviour characterized by both suppressed vocalization and motor activity (Ginsburg et al. 1974; Jones et al. 1992). According to this link, an increased concentration of testosterone in egg yolk resulted in more fearful performance of hatchlings in the open-field test and followed a similar trend in all three experiments. Quail hatched from testosterone-treated eggs showed longer latency to leave the start square, decreased locomotion, enhanced defecation and lower number of distress calls as compared to control birds. 
The results of the tonic immobility test were indicative of increased fearfulness of chicks exposed to elevated testosterone in egg yolk and this test would be considered analogous to an anti-predator response (Gallup 1979). Measuring tonic immobility responses is commonly used to assess an innate degree of fear since individuals with higher fearfulness display longer duration of TI and lower number of TI inductions (Jones et al. 1994; Marin et al. 2001). This pattern was observed among birds hatched from eggs treated with the highest dose of testosterone. Quail were more sensitive to induce TI and simultaneously delayed in awakening from the TI state as compared to birds in the control group.

While we examined three different concentrations of testosterone, one could expect to distinguish their effects in a dose-dependent manner. In actuality, TI duration was prolonged and number of attempts to induce TI was lower with each increasing dose of testosterone. Conversely, a dose-dependency in relation to behavioural parameters recorded in the openfield test was not observed.

The role of androgens is well-documented in the regulation of many physiological and behavioural processes and in a social context in which androgens activate and regulate aggressive and reproductive behaviour (Schlinger et al. 2001; Ros et al. 2002). Published studies in altricial birds demonstrate that experimental elevation of yolk testosterone produces positive effects on begging behaviour of offspring and on their competitive abilities (Schwabl 1996; Strasser and Schwabl 2004). In contrast to these stimulating effects, suppressed behavioural responses among 2-day-old quail hatched from testosteronetreated eggs were observed in the current study. Nonetheless, these data correspond with the hypothesis that increased testosterone content in yolk differentially influences behaviour of Japanese quail during ontogeny (Okuliarová et al. 2006). Previous works have shown that beginning the second week post-hatch, quail treated with in ovo testosterone injection express higher general activity in response to an unknown environment (Okuliarová et al. 2006) and are less fearful in a novel object test and test of tonic immobility (Daisley et al. 2005). Explanation of this phenomenon requires further study. It is likely that fearfulness exhibited among newly hatched chicks may affect their sensitivity to any disturbances from the environment and may impact their long-term behaviour (Heiblum et al. 1998; RichardYris et al. 2005). During this short post-hatch period, a critical stage for successful survival, increased fearful behaviour may represent an appropriate response to external challenges. Later, depending on prevailing environmental conditions and ontogenetic development, birds may improve their capability to cope actively with challenging situations and they turn their behavioural strategy in a "proactive" instead of "reactive" manner.

In conclusion, experimentally increased testosterone content in egg yolk elicited more intense fear-related responses of quail hatchlings during their early ontogeny. Measurable behavioural consequences with the lowest testosterone dose suggest that very slight fluctuations in yolk androgens may impact performance of future offspring. Further studies will focus on natural variability of yolk testosterone levels in eggs of precocial Japanese quail.

\section{Účinok zvyšujúcich sa koncentrácií testosterónu vo vajci na správanie vyliahnutých mlád'at prepelice japonskej}

Ciel’om našej práce bolo zistit’ vplyv zvýšeného obsahu testosterónu vo vajci na správanie jedno- a dvoj- dňových mlád’at prepelice japonskej. V rámci troch samostatných experimentov sme použili tri odlišné koncentrácie testosterónu $(0,25 ; 2,5$ a 25 ng), ktoré zvýšili obsah endogénnych androgénov vo vajci v rozsahu fyziologických hodnôt. Pri experimentálnej manipulácii bol použitý testosterón propionát riedený v objeme $20 \mu$ l olivového oleja a injekčne aplikovaný do vajcového žĺtka pred začiatkom inkubácie vajec.

Správanie vyliahnutých mlád’at bolo zaznamenávané v testoch otvoreného pol’a a tonickej imobility, ktoré umožňujú hodnotit' strachom podmienené reakcie testovaných zvierat. 
V teste otvoreného pol’a sa dôsledky zvýšeného testosterónu vo vajci prejavili pri všetkých troch aplikovaných koncentráciách a súhlasne potvrdzovali inhibíciu behaviorálnych prejavov mlád'at. Prepelice vyliahnuté z testosterónom ovplyvnených vajec vykazovali dlhšiu pohybovú latenciu, zníženú lokomočnú aktivitu, zvýšenú defekáciu a nižší počet úzkostných hlasových prejavov v porovnaní s kontrolou. V teste tonickej imobility sa vplyv testosterónu manifestoval iba pri najvyššej aplikovanej koncentrácii. Mlád'atá, vystavené v štádiu embrya experimentálne zvýšeným hladinám testosterónu, sa vyznačovali dlhšou tonickou imobilitou a nižším počtom pokusov potrebných na jej indukciu v porovnaní s kontrolnou skupinou.

Naše výsledky demonštrovali, že vyšší obsah testosterónu vo vajci sa prejavuje na intenzívnejších strachom podmienených reakciách mlád'at prepelice japonskej. S ohl'adom na predchádzajúce práce, ktoré preukázali stimulačný vplyv testosterónu vo vajci na správanie prepelíc v neskoršom vývinovom štádiu, sa zdá, že inhibičný účinok testosterónu u prekociálnych vtákov je obmedzený na obdobie krátko po vyliahnutí.

\section{Acknowledgement}

This study was supported by the grant VEGA No. 1/43434/07.

\section{References}

DAISLEY JN, BROMUNDT V, MÖSTL E, KOTRSCHAL K 2005: Enhanced yolk testosterone influences behavioral phenotype independent of sex in Japanese quail chicks Coturnix japonica. Horm Behav 47: 185-194

EISING CM, GROOTHUIS T 2003: Yolk androgens and begging behaviour in black-headed gull chicks: an experimental field study. Amin Behav 66: 1027-1034

GALLUP GG Jr 1979: Tonic immobility as a measure of fear in domestic fowl. Anim Behav 20: 166-169

GINSBURG HJ, BRAUD WG, TAYLOR RD 1974: Inhibition of distress vocalizations in the open field as a function of heightened fear or arousal in domestic fowl (Gallus gallus). Amin Behav 22: 745-749

GROOTHUIS TGG, CARERE C 2005: Avian personalities: characterization and epigenesis. Neurosci Biobehav Rev 29: 137-150

GROOTHUIS TGG, MÜLLER W, VON ENGELHARDT N, CARERE C, EISING CM 2005: Maternal hormones as a tool to adjust offspring phenotype in avian species. Neurosci Biobehav Rev 29: 329-352

HACKL R, BROMUNDT V, DAISLEY J, KOTRSCHAL K, MÖSTL E 2003: Distribution and origin of steroid hormones in the yolk of Japanese quail eggs (Coturnix coturnix japonica). J Comp Physiol B 173: 327-331

HAYWARD LS, SATTERLEE DG, WINGFIELD JC 2005: Japanese quail selected for high plasma corticosterone response deposit high levels of corticosterone in their eggs. Physiol Biochem Zool 78: 1026-1031

HEIBLUM R, AIZENSTEIN O, GVARYAHU G, VOET H, ROBINZON B, SNAPIR N 1998: Tonic immobility and open field responses in domestic fowl chicks during the first week of life. Appl Anim Behav Sci 60: 347-357

HORTON TH 2005: Fetal origins of developmental plasticity: animal models of induced life history variation. Am J Hum Biol 17: 34-43

JONES RB, MILLS AD, FAURE JM, WILLIAMS JB 1994: Restraint, fear, and distress in Japanese quail genetically selected for long or short tonic immobility reactions. Physiol Behav 56: 529-534

JONES RB, SATTERLEE DG, RYDER FH 1992: Research note: open-field behavior of Japanese quail chicks genetically selected for low or high plasma corticosterone response to immobilization stress. Poult Sci 71: 1403-1407

KARADAS F, PAPPAS AC, SURAI PF, SPEAKE BK 2005: Embryonic development within carotenoid-enriched eggs influences the post-hatch carotenoid status of the chicken. Comp Biochem Physiol B 141: 244-251

MARIN RH, FREYTES P, GUZMAN D, JONES RB 2001: Effects of an acute stressor on fear and on the social reinstatement responses of domestic chicks to cagemates and strangers. Appl Anim Behav Sci 71: 57-66

MARIN RH, MARTIJENA ID, ARCE A 1997: Effect of diazepam and A beta-carboline on open-field and T-maze behaviors in 2-day-old chicks. Pharmacol Biochem Behav 58: 915-921

OKULIAROVÁ M, KOSTAL L, ZEMAN M 2006: Increased testosterone content in egg differentially influences behaviour of Japanese quail during ontogeny. In: YAHAV, S, TZSCHENTKE B (Eds.): New Insights into Fundamental Physiology and Peri-natal Adaptation of Domestic Fowl. Nottingham University Press, United Kingdom, pp 173-180.

PILZ KM, SMITH HG, SANDELL MI, SCHWABL H 2003: Interfemale variation in egg yolk androgen allocation in the European starling: do high-quality females invest more? Amin Behav 65: 841-850

REED WL, VLECK CM 2001: Functional significance of variation in egg-yolk androgens in the American coot. Oecologia 128: 164-171 
RICHARD-YRIS MA, MICHEL N, BERTIN A 2005: Nongenomic inheritance of emotional reactivity in Japanese quail. Dev Psychobiol 46: 1-12

ROS AF, DIELEMAN SJ, GROOTHUIS TG 2002: Social stimuli, testosterone, and aggression in gull chicks: support for the challenge hypothesis. Horm Behav 41: 334-342

SCHLINGER BA 1998: Sexual differentiation of avian brain and behavior: Current views on gonadal hormonedependent and independent mechanisms. Annu Rev Physiol 60: 407-429

SCHLINGER BA, SOMA KK, SALDANHA CJ 2001: Advances in avian behavioral endocrinology. Auk 118: 283-289

SCHWABL H 1996: Maternal testosterone in the avian egg enhances postnatal growth. Comp Biochem Physiol 114: $271-276$

STRASSER R, SCHWABL H 2004: Yolk testosterone organizes behavior and plumage coloration in house sparrows (Passer domesticus). Behav Ecol Sociobiol 56: 491-497

SURAI PF, IONOV IA, KUKLENKO TV, KOSTJUK IA, MACPHERSON A, SPEAKE BK, NOBLE RC, SPARKS NH 1998: Effect of supplementing the hen's diet with vitamin A on the accumulation of vitamins A and E, ascorbic acid and carotenoids in the egg yolk and in the embryonic liver. Br Poult Sci 39: 257-263 